\title{
The Biochemical Biomarkers Determination in Alzheimer Dementia
}

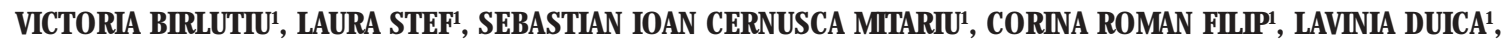 \\ ELISABETA ANTONESCU1*, MIHAIL PIRLOG², TRAIAN PURNICHI², SINZIANA CALINA SILISTEANU', \\ MARINELA MINODORA MANEA ${ }^{4,5}$ \\ 'Lucian Blaga University of Sibiu, Faculty of Medicine, 2A Lucian Blaga Str., 550169, Sibiu, Romania \\ UUniversity of Medicine and Pharmacy of Craiova, Faculty of Medicine, Craiova, Romania \\ ${ }^{3}$ Stefan cel Mare University of Suceava, Department of Health and Human Development, 13 Universitatii Str., 720229, Suceava, \\ Romania \\ ${ }^{4}$ Iuliu Hatieganu University of Medicine and Pharmacy, Department of Medical Psychology, 8 Victor Babes Str, 400012, ClujNapoca, \\ Romania \\ ${ }^{5}$ County Emergency Clinical Hospital ClujNapoca, Psychiatric Clinic 3, 3-5 Clinicilor Str., 400000, Cluj-Napoca, Romania
}

\begin{abstract}
Alzheimer's disease $(A D)$ is a complex neuropsychiatric condition characterized by progressive cognitive symptoms. The social and psychological costs associated with the care of AD patients are very high; therefore, significant funds for research in this field are being invested worldwide. The accuracy of medical methods for establishing the diagnosis of $A D$ with specific neuropathology is very important. Biomarkers can detect $A D$ in their pre-clinical stage, monitor the disease progression, and detectmore objectively the treatment response. We performed a retrospective study of 100 patients admitted to the Gheorghe Preda Psychiatric Hospital of Sibiu with the diagnosis of Mild Cognitive Impairment and Alzheimer's Dementia. The diagnosis was established according to the Diagnostic and Statistical Manual Disorders-4th edition criteria and the severity of the condition was determined by the Mini Mental State Examination. Our retrospective study revealed that in a certain period of time, most hospitalized patients with $A D$ had the most days of hospitalization; they were patients in severe stage, due to the needs of multidisciplinary care and the multiple possibilities offered by medical staff. At present, $A D$ research, in addition to finding therapeutic remedies in the clinical stages of $A D$, also aims at primary and secondary prevention strategies, including the detection of biomarkers in the pre-clinical stage of $A D$.
\end{abstract}

Keywords:Alzheimer's disease, diagnosis, amyloidplaques, protein

Alzheimer's disease (AD) is a complex neuropsychiatric condition characterized by progressive cognitive symptoms and a very well-studied neuropathology consisting mainly in amyloid plaques and neurofibrillary tangles [1].

The accuracy of clinical methods for establishing the diagnosis of AD with specific neuropathology is rather low, with a sensitivity of 71 to $80 \%$ and a specificity between 44 and $70 \%$ (according to the histopathological criteria used) [2].

For a more objective diagnosis, in the case of $A D$, we have several biomarkers: magnetic resonance imaging (MRI), Fluoro-deoxy-glucose positron emission tomography (FDG-PET) and proteins in cerebrospinal fluid (CSF) [3]. MRI and PET do not directly measure the neuropathological indicators of the disease, so the most valid measurements remain those of Amyloid $\beta$ protein $\left(A \beta_{12}\right)$,phosphorylated tau protein ( $p$-tau) and total tau protein (t-tau) in CSF [4].

Biomarkers can detect $A D$ in their pre-clinical stage, monitor the disease progression, detect treatment response more objectively [5].

According to WHO statistics, in the period 2000-2010, the number of deaths due to $A D$ increased by $68 \%$, while other diseases, including cardiovascular diseases and cancer decreased [6]. The social and psychological costs associated with the care of AD patients are very high; it is expected that in the United States, it will exceed \$ 1 trillion by 2050 [ 7],therefore, significant funds for research in this field are being invested worldwide.
Pathophysiology of Alzheimer Dementia

Amyloid plaques are composed of amyloid fibrils with a surrounding of dystrophic neurites and activated astrocytes and microglia. The main protein of amyloid plaques is the $A \beta$ peptide. $A \beta$ is generated from $A \beta$ precursor protein (APP) when a $\beta$ secretase cleaves to form c99, a membrane-bound C-terminal fragment [8]. Furthermore, c99 is cleaved by $\gamma$ - secretase and generates $A \beta 40$ and $A \beta$ 42 [9]. The aggregation of $A \beta$ peptides is enhanced by excess free amount of $\mathrm{Zn}, \mathrm{Fe}, \mathrm{Cu}, \mathrm{Al}$.

An imbalance between the production and clearance or degradation or clearance of $A \beta$ in the brain [10] is the initiating event in $A D$. $A \beta$ peptides are promising candidate biological markers because they may exist in solution and can be detected in CSF and plasma [11]. Further reactive oxygen species (ROS) and inflammation promotes loss of synaptic integrity, neuronal death and progressive neurodegeneration [12].

Neurofibrillary tangles are formed by the hyper phosphorylation and aggregation of tau protein of numerous serine and threonine residues [13]. The tau protein is a constituent of neuronal microtubules which are cell structures responsible for the motility of proteins and organelles within the neuron [14]. Abnormal tau hyperphosphorylation deposits in $A D$ are observed within neurons, NFTs, or dystrophic neurites present in neuritic plaques [15]. Because of aberrant phosphorylation, tau protein cannot bind and stabilize the microtubules, which is likely to induce axonal [16].

There was no correlation between the amount of amyloid plaque and the level of dementia. Certain patients

* email :bety_antonescu@yahoo.com; Phone: 0723610900

REV.CHIM.(Bucharest) 69 No.11 $2018 \quad$ http://www.revistadechimie.ro 
who were diagnosed with AD did not show amyloid plaques, whereas in cognitively healthy individuals, amyloid plaques were not identified at autopsy. At the same time, the existence of the amyloid plaque in patients presenting preclinical AD can be excluded. Amyloid plaque formation is believed to mark the event of generating more toxic and soluble forms of $A \beta$. T-tau is a good predictive marker to make a difference between stable Mild cognitive impairment $(\mathrm{MCl})$ and $\mathrm{MCl}$ that converts to $\mathrm{AD}$ with a sensitivity of $90 \%$ and $100 \%$ specificity. The cognitive decline in $\mathrm{MCl}$ patients correlates with $\mathrm{P}$-tau concentrations in CSF [17]. Also, the increased level of T-tau in CSF also reflects the severity of dementia [18].

\section{Evolution of assessing biomarkers in Alzheimer disease}

Because CSF is in a contact with cerebral tissues, then the pathological brain changes can be reflected as a source of biomarkers [19]. The term biomarkerwas described as any neurochemical indicator that is used to diagnose Alzheimer's disease in the clinical and pre-clinical disease stages [20]. A $\beta_{42}$ and t-tau have been considered as diagnostic biomarkers as follows: T-tau levels are elevated and $A \beta_{42}$ levels decreased in CSF of AD patients [21]. Decreased $A \beta_{42}$ levels in AD are believed to be caused by deposition of Áp42 in senile plaque [22].

These biomarkers were measured using the ELISA technique, including a T-tau protein assay that measures all of tau protein isoforms [23], respectively of the phosphorylated tau protein at the level of threonine-181 [24] and the 42-amino acid forms of $A \beta$ [25].

The first trials that examined CSF $A \beta$ level focused on the total $A \beta$ in CSF and did not distinguish between the $A \beta$ isoforms. Some studies have shown a slight decrease in total $A \beta$ [26] or have not detected any change in the total Aâ level in $A D$ [27]. There are two main variants of Aâ: the shorter version presenting Val-40 (A $\beta 40)$ at the $C$-terminus end and the longer variant having Ala-42 (AB42) at the Cterminus end. Of these, $A \beta 42$ was found to aggregate much faster than $A \beta 40$, being the predominant form found in the amyloid plaques [28].

The first study assessing CSF A beta 42 levels showed significantly lower levels in AD patients relative to controls. Because $A$ beta 42 is preferentially deposited in brain tissue of patients with $A D$, it is suggested that this reduction is due to the diminished clearance; in addition, tau levels were increased in $A D$ patients. Neither $A$ beta 42 nor tau levels were apparently influenced by the ApoE genotype [29].

Subsequently most studies have confirmed these findings [30]. Increased CSF A 42 levels in mild AD and its decline has been registered with the disease progression [31] and with brain atrophy [32].

The first study of the T-tau protein in the CSF as a biomarker for $A D$ revealed an increased marked level of this one in $A D$ [33]. At least 30 phosphorylation sites of tau protein have been identified. Several studies showing a marked increase in CSF P-tau targeted phosphorylation of several epitopes, such as threonine $181+231$ [34], threonine 181 [35], threonine $231+$ serine 235, serine 199 [36], threonine 231 [37].

In a study evaluating the combination of CSF P-tau 181 and $A \beta 42$, the sensitivity was $86 \%$ and the specificity was $97 \%$ [38] in another combination, T-tau and P-tau 396/404 had a sensitivity of 96 and $100 \%$ specificity [39].

The T-tau protein in CSF reflects the neuronal and axonal degeneration, so the higher values are recorded in stokes, i.e. Creutzfeld-J acob disease [40].
In order to differentiate between $A D$ and other forms of dementia, the $p$-tau $/ A \beta 42$ or t-tau/A $\beta 42$ ratio is used, with a sensitivity of up to $92 \%$ and a specificity of up to $86 \%$. The ratio between $A \beta 42$ and $p$-tau is significantly lower in $A D$ patients compared to those with vascular dementia [41].

According to the report issued by the Working Group on Biomarkers in $A D$, demonstrating the validity of a biomarker if the sensitivity and specificity are greater than $80 \%$, this study showed that the discrimination between $A D$ and vascular dementia can be made based on the ratio between A42 and p-tau(20). This ratio also helps distinguishing between $A D$ and FTD, PD, but it is not as clear in the case of dementia with Lewy bodies and vascular dementia [42].

Another utility of the mentioned biomarkers is to predict the conversion of $\mathrm{MCl}$ to $\mathrm{AD}$. Thus, low $\mathrm{A} \beta 42$ and increased t-tau or $p$-tau have also shown their accuracy in the distinction between normal aging and $A D(>85 \%)$ and have a good predictive value in predicting $\mathrm{MCl}$ conversion to $A D(>90 \%)$ [43]. Another role of biomarkers may be to establish thedynamics of NFT development in the preclinical stage. Thus, p-tau growth at S262 or S181 appears early in NFT development, and S396 level rise occurs in advanced stages [44].

Links between the biomarkers and clinical features in $A D$ In 1984, NINCDS-ADRDA criteria have been issued presenting the criteria for Probable AD dementia, Possible $A D$ dementia, Probable or possible $A D$ dementia with evidence of the AD pathophysiological process [45]. These criteria aimed at the dementia syndrome containing the classical clinical features of $A D$ as well as the exclusion of other causes of non-degenerative dementia.

Regarding the Possible AD dementia with evidence of the $A D$ pathophysiological process, the review of the clinical criteria took into account the measurement of the following biomarkers: AB42 low in the CSF, increased tau in the CSF (tau and p-tau), MRI showing cortical atrophy in the medial, basal, temporal lateral and medial parietal cortex, PET showing the decreased capture of fluorodeoxy-glucose in the temporo-parietal cortex [46].

The guideline recommended by The National Institute on Aging and Alzheimer's Association (NIA-AA) makes a very important assumption about the preclinical stages of AD. In stage 1, asymptomatic amyloidosis is evident by increased PET A $\beta$ ligand binding and low CSF $A b_{1-42}$ levels. Stage 2 includes neurodegeneration evidenced by neuronal dysfunction based on neuroimaging (PET, MRI) high CSF tau or $p$-tau concentrations cortical thinning and hippocampal atrophy (MRI). Stage 3 is evidenced by amyloidosis, neurodegeneration, and subtle cognitive decline as evidenced by mild change from baseline cognitive function that does not meet criteria for MCl [47].

\section{Experimental part}

We performed a retrospective study of 100 patients admitted to the Gheorghe Preda Psychiatric Hospital of Sibiu with the diagnosis of Mild Cognitive Impairment and Alzheimer's Dementia. The diagnosis was established according to the Diagnostic and Statistical Manual Disorders, $4^{\text {th }}$ edition (DSM IV) criteria and the severity of the condition was determined by the Mini Mental State Examination (MMSE). Of the total of 100 patients studied, $52 \%$ were males and $48 \%$ were females, $54 \%$ of the patients were rural and $46 \%$ were urban.

\section{Results and discussions}

It can be seen that of the majority of patients in the age group of 55-65 years, most patients are in the prodromal 


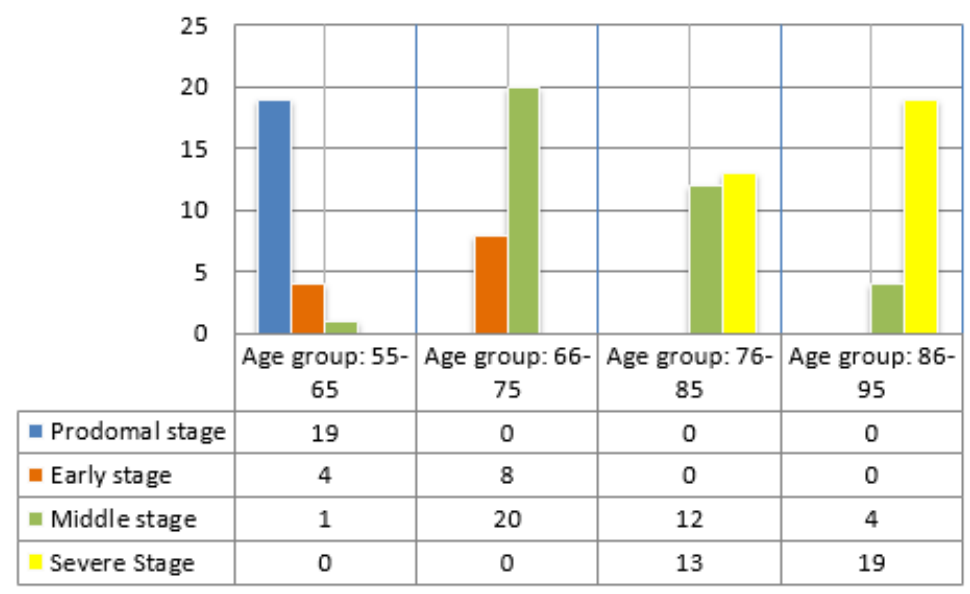

Fig.1. Patients' repartition according to age and stage of disease

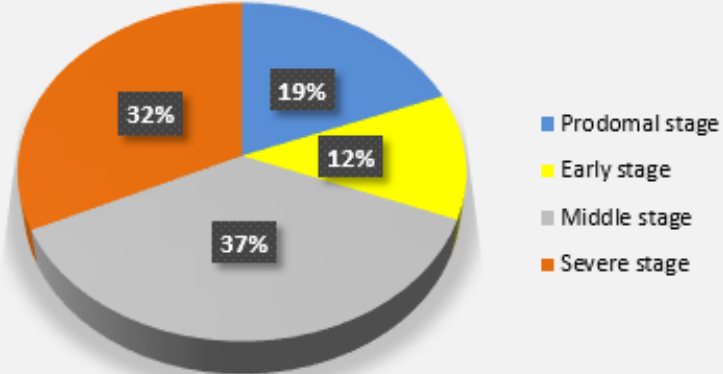

Fig.2. Patients' repartition according to the stage of disease

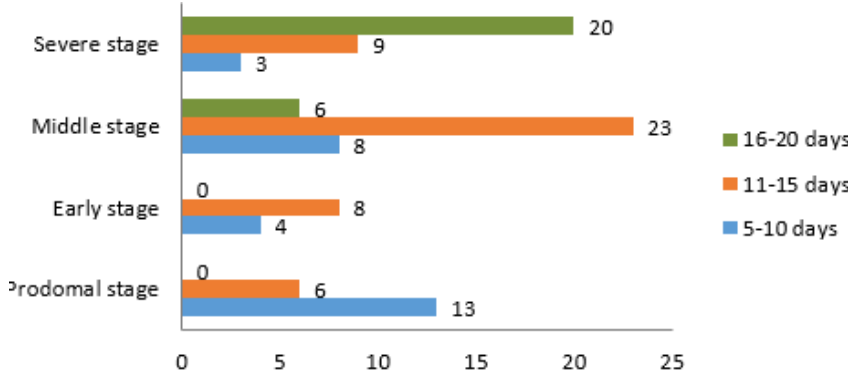

Fig.3. Patients' distribution according to the number of hospitalization days and stage of disease

phase $(\mathrm{MCl})$; In the age group of $66-75$ years, most patients are in the middle stage; In the 76-85 age group, most of them are in the middle to severe stage and in the age group of 86-85 years, most patients are in a severe stage.

It can be seen that out of a total of 100 patients, most are in the middle (37\%) and severe (32\%) stages.

Our study reveals that there are an increased number of patients with moderate and severe Alzheimer's Dementia, and also an increased number of days of hospitalization in these patients.

Moderate dementia is associated with loss of ability to perform daily activities and requiring patient placement in a care center, which requires very high costs for society. In this respect, much research focused on one hand, on finding biomarkers to reveal the conversion of $M C I$ to $A D$ and the progression of mild dementia into moderate dementia.

In mild cognitive impairment, a cognitive disorder that is considered an intermediary stage between normal aging and $A D$, values of the biomarkers in CSF detectable in $A D$ $A \beta 42$, tau and $p$-tau were found at intermediate levels between the values found in AD cases and in control cases [48].

Overlapping values were found in patients with $\mathrm{MCl}$ versus those with $A D$, two thirds of those with $M C l$ having the same biomarker profile as AD patients, one third of them having normal values [49].
The increase in protein t-tau is very high in disorders with intense neurodegeneration, as in Creutzfeldt-jakob disease. How ever, most cross-sectional studies do not describe any association between tau protein levels and the stage of dementia. However, most longitudinal studies have focused on the distinction between $A D$ and control cases or cases with $\mathrm{MCl}$, based on changes in tau protein.

In a study aiming at the relationship between tau protein levels in CSF and the time the person gets in a care center (NHP), it has been highlighted that elevated levels of tau protein (> $900 \mathrm{ng} / \mathrm{L}$ ) have been associated with the increased rate of conversion to moderate dementia, both from the preclinical stage and from the $\mathrm{MCl}$ stage [50] (fig. 4).

This study reveals an association between the rapid decline of the disease and the high levels of tau protein in the CSF, more than in the case of $A \beta 42$ or $p$-tau, which could indicate in the future, its selection as a predictive marker for an aggressive neurodegeneration.

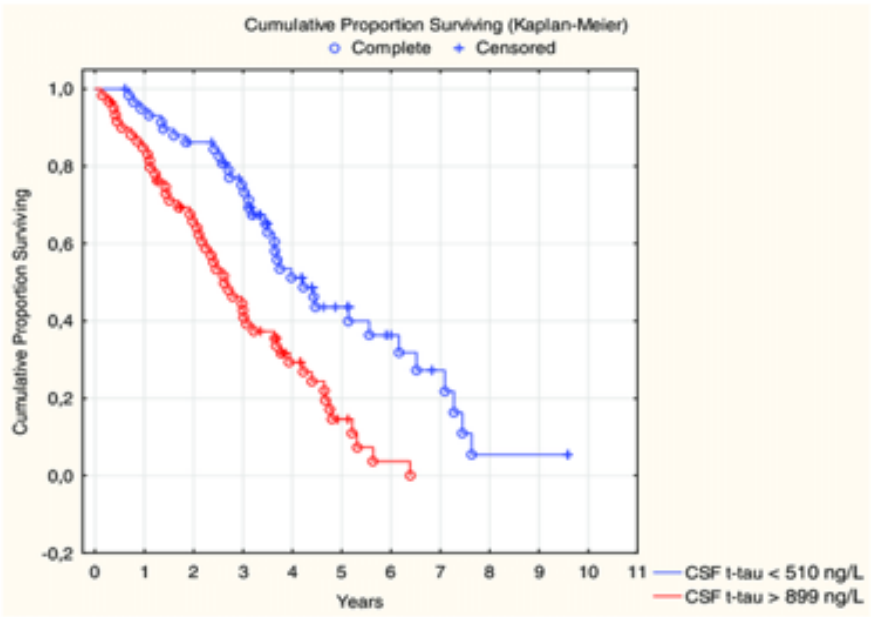

Fig. 4. CSF t-tau associated with the highest risk of being institutionalized [50]

\section{Conclusions}

Although $A \beta 42$, tau and $p$-tau measurements in the CSF can be performed in the clinical setting in the United States and some European countries, still, they are not part of the clinical criteria of AD according to DSM IV. Other diagnostic systems such as NINCDS- ADRDA and NIA-AA included biomarkers measurement in both $A D$ and $\mathrm{MCl}$ diagnosis and of the preclinical stage. The area of biomarkers research now extends to their identification and measurement in plasma as well, which can facilitate even more the investigation of the biomarkers.

The medical objectives in the $A D$ are to detect the disease at an early stage, both from the point of view of clinical symptoms and with the use of scientifically 
validated biomarkers. Our retrospective study revealed that in a certain period of time, of the patients hospitalized with $A D$, most patients and who had the most days of hospitalization were patients in severe stage, due to the needs of multidisciplinary care and the multiple possibilities offered by medical staff [51]. So that, visual impairments, hearing loss, osteoarthritis [52], clinical conditions like urinary tract infections, pneumonia, or heart failure or sentinel events (e.g., eating difficulties, recurrentinfections, hip fracture, stroke) influence severly the quality of life and prognostication [53].

At present, $A D$ research, in addition to finding therapeutic remedies in the clinical stages of $A D$, also aims at primary and secondary prevention strategies, including the detection of biomarkers in the pre-clinical stage of $A D$.

Acknowledgements: This study, being a retrospective one, did not require a written consent from the patients involved. All authors had equal scientific contribution in publishing this material.

\section{References}

1.THAL, D.R., RUB, U., ORANTES, M., BRAAK, H. Phases of Abetadeposition in the human brain and its relevance for the development of AD. Neurology 2002; 58: p791-800.

2.BEACH, T.G., MONSELL, S.E., PHILLIPS, L.E., KUKULL, W. Accuracy of the clinical diagnosis of Alzheimer disease at National Institute on Aging Alzheimer Disease Centers, 2005-2010.J NeuropatholExp Neurol. 2012; 71(4):p266-73.

3.BLENNOW, K., HAMPEL, H., WEINER, M., ZETTERBERG, H. Cerebrospinal fluid and plasma biomarkers in Alzheimer disease.Nat Rev Neurol 2010; 6(3):p131-44.

4.BLENNOW K, ZETTERBERG H, FAGAN AM. Fluid biomarkers in Alzheimer disease. Cold Spring HarbPerspect Med. 2012;2:a006221.

5.WATTAMWAR, P.R., MATHURANATH, P.S. An overview of biomarkers in Alzheimer disease. Ann Indian Acad Neurol. 2010;13(Suppl 2) : p116123.

6.THIES W, BLEILER L, Alzheimer A. 2013 Alzheimer disease facts and figures. Alzheimers Dement 2013;9: p 208-245.

7.STEFANACCI RG. The costs of Alzheimer disease and the value of effective therapies. Am J ManagCare 2011;17(Suppl 13):p 356-362.

8.ZHANG, C. Natural Compounds That Modulate BACE1-Processing of Amyloid-Beta Precursor Protein in Alzheimer Disease. Discov. Med. 2012;14:p189-197.

9.HAASS, C. Take ve-BACE and the gamma-secretase quartet conduct Alzheimer's amyloid beta-peptide generation. EMBO J 2004; 23: p 483-488.

10.HARDY, J., SELKOE, D.J. The amyloid hypothesis of Alzheimer disease: progress and problems on the road to therapeutics. Science 2002; 297: p 353-356.

11.BLENNOW, K., HAMPEL, H. CSF markers for incipient Alzheimer's disease. Lancet Neurol. 2003;2: p 605-613.

12.FRANK, R.A., GALASKO, D., HAMPEL, H., HARDY, J., DE LEON, M.J., MEHTA, P.D., ROGERS, J., SIEMERS, E., TROJ ANOWSKI, J.Q. Biological markers for therapeutic trials in Alzheimer disease. Proceedings of the biological markers working group; NIA initiative on neuroimaging in Alzheimer $s$ disease. Neurobiol Aging 2003; 24: $p$ 521-536.

13.SERGEANT N., DELACOURTE, A., BUEE, L. Tau protein as a differential biomarker of tauopathies, BiochimicaetBiophysicaActa 2005; 1739(2): p 179-197.

14.WEINGARTEN, M.D., LOCKWOOD, A.H., HWO, S.Y., KIRSCHNER, M.W. A protein factor essential for microtubule assembly. Proc Natl AcadSciUSA. 1975;5:1858-1862.

15.HALL, G.F., LEE, V.M., KOSIK, K.S. Microtubule destabilization and neurofilament phosphorylation precede dendritic sprouting after close axotomy of lamprey central neurons. Proc Natl AcadSci USA. 1991;5: p 5016-5020.
16.MANDELKOW, E.M., MANDELKOW, E. Tau in Alzheimer's disease. Trends Cell Biol. 1998;8: p 425-427.

17.HUMPEL, C., HOCHSTRASSER T. Cerebrospinal fluid and blood biomarkers in Alzheimer's disease, World Journal of Psychiatry 2011;1(1): p 8-18.

18.BLOM, E.S., GIEDRAITIS, V., ZETTERBERG, H., FUKUMOTO, H., BLENNOW, K., HYMAN, B.T., et al. Rapid progression from mild cognitive impairment to Alzheimer disease in subjects with elevated levels of tau in cerebrospinal fluid and the APOE å4/å4 genotype. Dement GeriatrCognDisord. 2009;27:p458-464.

19.REIBER, H. Dynamics of brain-derived proteins in cerebrospinal fluid. ClinChimActa 2001;310: p 173-186.

20.*** THE RONALD AND NANCY REAGAN RESEARCH INSTITUTE OF THE ALZHEIMER ASSOCIATION AND THE NATIONAL INSTITUTE ON AGING WORKING GROUP. Consensus report of the Working Group on. Molecular and Biochemical Markers of Alzheimer Disease. Neurobiol Aging 1998;19:p109-116.

21.VERBEEK, M.M., DE JONG, D., KREMER, H.P. Brain-specific proteins in cerebrospinal fluid for the diagnosis of neurodegenerative diseases. Ann Clin Biochem.2003;40:p25-40.

22.STROZYK, D., BLENNOW, K., WHITE, L.R., LAUNER, L.J . CSF Abeta 42 levels correlate with amyloid-neuropathology in a population-based autopsy study. Neurology. 2003;60: p652-656.

23.BLENNOW, K., WALLIN, A., AGREN, H., SPENGER, C., SIEGFRIED, J., VANMECHELEN, E. Tau protein in cerebrospinal fluid - A biochemical marker for axonal degeneration in Alzheimer disease? MolChemNeuropathol. 1995; 26(3):p231-245.

24.VANMECHELEN, E., VANDERSTICHELE, H., DAVIDSSON, P., VAN KERSCHAVER, E., VAN DER PERRE, B., SJ OGREN, M., ANDREASEN, N., BLENNOW, K.Levels of nonphosphorylated and phosphorylated tau in cerebrospinal fluid of Alzheimer disease patients: an ultrasensitive bienzyme-substrate-recycle enzyme-linked immunosorbent assay. Neurosci Lett. 2000; 285(1): p49-52.

25.ANDREASEN, N., MINTHON, L., CLARBERG, A., DAVIDSSON, P., GOTTFRIES, J., VANMECHELEN, E. et al. Sensitivity, specificity and stability of CSF-tau in AD in a a community-based patient sample. Neurology 1999; 53(7):p1488-1494.

26.VAN NOSTRAND, W.E., WAGNER, S.L., SHANKLE, W.R., FARROW, J.S., DICK, M., ROZEMULLER, J.M. et al. Decreased levels of soluble amyloid â-protein precursor in cerebrospinal fluid of live Alzheimer disease patients. Proc Natl AcadSci USA, 1992, 89: p2551-2555.

27.SOUTHWICK, P.C., YAMAGATA, S.K., ECHOLS, C.L., JR., HIGSON, G.J., NEYNABER, S.A., PARSON, R.E., MUNROE, W.A. Assessment of amyloid beta protein in cerebrospinal fluid as an aid in the diagnosis of Alzheimer's disease. J Neurochem. 1996; 66(1):p259-265.

28.IWATSUBO, T., ODAKA, A., SUZUKI, N., MIZUSAWA, H., NUKINA, N., IHARA, Y. Neuron. 1994; 13(1):p45-53.

29.MOTTER, R., VIGO-PELFREY, C., KHOLODENKO, D., BARBOUR, R., JOHNSON-WOOD, K., GALASKO, D., et al. Reduction of b-amyloid peptide42 in the cerebrospinal fluid of patients with Alzheimer disease. Ann Neurol. 1995;38:p643-648.

30.GALASKO, D., CHANG, L., MOTTER, R., CLARK, C.M., KAYE, J., KNOPMAN, D., THOMAS, R., KHOLODENKO, D., SCHENK, D., LIEBERBURG, I., MILLER, B., GREEN, R., BASHERAD, R., KERTILES, L, BOSS, M.A., SEUBERT, P. High cerebrospinal fluid tau and low amyloid â 42 levels in the clinical diagnosis of Alzheimer disease and relation to apolipoprotein E genotype. Arch Neurol 1998;55:p937-945. 31.J ENSEN, M., SCHRODER, J., BLOMBERG, M., ENGVALL, B., PANTEL, J., IDA, N., BASUN, H., WAHLUND, L.O., WERLE, E., JAUSS, M., BEYREUTHER, K., LANNFELT, L., HARTMANN T. Cerebrospinal fluid $A \beta 42$ is increased early in sporadic Alzheimer disease and declines with disease progression. Ann Neurol 1999;45:p504-511.

32.SCHRO DER, J., PANTEL J, IDA, N., ESSIG, M., HARTMANN, T., KNOPP, M.V., SCHAD, L.R., SANDBRINK, R., SAUER, H., MASTERS, C.L., BEYREUTHER K. Cerebral changes and cerebrospinal fluid â amyloid in Alzheimer's disease: a study with quantitative magnetic resonance imaging. Mol Psychiatry 1997;2:p505-507. 
33.VANDERMEEREN, M., MERCKEN, M., VANMECHELEN, E., SIX, J., VAN DE VOORDE, A., MARTIN, J.J., CRAS, P. Detection of tau proteins in normal and Alzheimer disease cerebrospinal fluid with a sensitive sandwich enzyme-linked immunosorbent assay. J Neurochem. 1993; 61(5):p 1828-1834.

34.BLENNOW, K., WALLIN, A., AGREN, H., SPENGER, C., SIEGFRIED, J., VANMECHELEN, E. Tau protein in cerebrospinal fluid: a biochemical marker for for axonal degeneration in Alzheimer disease? MolChemNeuropathol. 1995; 26(3):p231-245.

35.VANMECHELEN, E., VANDERSTICHELE, H., DAVIDSSON, P., VAN KERSCHAVER, E., VAN DER PERRE, B., SJ OGREN, M., et al. Quantification or tau protein phosphorylated at threonine 181 in human cerebrospinal fluid: a sandwich ELISA with a syntethicphosphopeptide for standardization. Neurosci Lett 2000; 285(1):p49-52.

36.ISHIGURO, K., OHNO, H., ARAI, H., YAMAGUCHI, H., URAKAMI, K., PARK, J.M., SATO, K., KOHNO, H., IMAHORI, K. Phosphorylated tau in human cerebrospinal fluid is a diagnostic marker for Alzheimer's disease. Neurosci Lett. 1999; 270(2):p91-94.

37.KOHNKEN, R., BUERGER, K., ZINKOWSKI, R., MILLER, C., KERKMAN, D., DE BERNARDIS, J., SHEN, J., MOLLER, H.J ., DAVIES, P., HAMPEL, H. Neurosci Lett. 2000; 287(3):p187-190.

38.MADDALENA, A., PAPASSOTIROPOULOS, A., MULLER-TILLMANNS, B., JUNG, H.H., HEGI, T., NITSCH, R.M. et al. Biochemical diagnosis of Alzheimer disease by measuring the cerebrospinal fluid ratio of phosphorylated tau protein to $\beta$-amyloid peptide42. Arch Neurol 2003;60:p1202-1206.

39.HU, Y.Y., HE, S.S., WANG, X., DUAN, Q.H., GRUNDKE-IQBAL, I., IQBAL K., WANG, J.Levels of nonphosphorylated and phosphorylated tau in cerebrospinal fluid of Alzheimer's disease patients: an ultrasensitive bienzyme-substrate-recycle enzyme-linked immunosorbent assay. Am J Pathol. 2002;160(4):p1269-1278.

40.SCHOONENBOOM, N.S., REESINK, F.E., VERWEY, N.A., et al. Cerebrospinal fluid markers for differential dementia diagnosis in a large memory clinic cohort. Neurology 2012;78:p47-54.

41.DE J ONG, D., JANSSEN, R.W.M.M., KREMER, B.P.H., Verbeek M.M. Cerebrospinal Fluid Amyloid $\beta_{42}$ /Phosphorylated Tau Ratio Discriminates Between Alzheimer Disease and Vascular Dementia, The J ournals of Gerontology 2006;61(7):p755-758.

42.TAPIOLA, T., ALAFUZOFF. I., HERUKKA, S-K., et al. Cerebrospinal Fluid beta-Amyloid 42 and Tau Proteins as Biomarkers of AlzheimerType Pathologic Changes in the Brain. Arch Neurol 2009;66:p382-389.
43.HANSSON, O., ZETTERBERG, H., BUCHHAVE, P., LONDOS, E., BLENNOW, K., MINTHON, L. Association between CSF biomarkers and incipient Alzheimer disease in patients with mild cognitive impairment: a follow-up study. Lancet Neurol 2006;5:p228-234.

44.MATTSSON, N., ROSEN, E., HANSSON, O., ANDREASEN, N., PARNETTI, L., JONSSON, M., et al. Age and diagnostic performance of Alzheimer disease CSF biomarkers. Neurology 2012;78: p468-476.

45.MCKHANN, G., DRACHMAN, D., FOLSTEIN, M., KATZMAN, R., PRICE, D, STADLAN, E.M. Clinical diagnosis of Alzheimer's disease: report of the NINCDS-ADRDA Work Group under the auspices of Department of Health and Human Services Task Force on Alzheimer Disease. Neurology. 1984;34:p939-944.

46.J ACK, C.R., JR, ALBERT, M.S., KNOPMAN, D.S., MCKHANN, G.M., SPERLING, R.A., CARRILLO, M.C., et al. Introduction to the recommendations from the National Institute on Aging-Alzheimer Association workgroups on diagnostic guidelines for Alzheimer disease. Alzheimers Dement. 2011;7:p257-262

47.FIANDACA, M.S., MAPSTONE, M.E., CHEEMA, A.K., FEDEROFF H.J . The critical need for defining preclinical biomarkers in Alzheimer disease. Alzheimer \& Dementia 2014;p196-212.

48.WEINER, M., VEITCH, D.P., AISEN, P.S., et al. The Alzheimer disease neuroimaging initiative: a review of papers published since its inception, Alzheimer \& Dementia 2013; 9(5):p111-194.

49.SHAW, L.M., VANDERSTICHELE H., KNAPIK-CZAJ KA, M. et al. Cerebrospinal fluid biomarker signature in Alzheimer disease neuroimaging initiative subjects. Annals of Neurology 2009;65(4):p403413.

50.DEGERMAN,G., INGELSSON, M., BLENNOW, K., BASUN, H., LANNFELT L, KILANDER, L. High tau levels in cerebrospinal fluid predict nursing home placement and rapid progression in Alzheimer disease. Alzheimers Res Ther 2016; p8-22.

51.COSTAN W, POPESCU E, STRATULAT SI. A new approach to aesthetic maxillofacial surgery: surgical treatment of unilateral exophthalmos due to maxillary sinus mucocele. J CraniofacSurg, Vol. 24, nr. 3, 2013, p. 914-916.

52.CIOBOTEA, D., VLAICU, B., ANAMARIA CIUBARA, A., DUICA C.L., COTOCEL, C., ANTOHI, V., PIRLOG, M.C. Visual Impairment in the Elderly and its Influence on the Quality of Life. Revista de CercetaresilnterventieSociala 2016;54:p66-74.

53.ARCAND, M. End-of-life issues in advanced dementia. Can Fam Physician 2015; 61(4):p330-334.

$\overline{\text { Manuscript received: } 18.02 .2018}$ 